\title{
APRESIASI TEMBANG PANDAI
}

\author{
M. AINUN NAJIB \\ Universitas Nahdlatul Ulama Sidoarjo
}
A. IDENTITAS PUISI
Judul puisi
: Pandai
Penulis
: Agung Purnomo
Jenis puisi
: Riddle
Bahasa
: Indonesia

\section{B. IDENTITAS BUKU}

Judul buku

Penyunting/editor

Desainer sampul

Desainer ilustrasi

ISBN

Penerbit

Tahun terbit

Percetakan

Harga

Lingkup penerbitan

Dimensi
: Tolesan Aditi

: Liahmad

: Nur Hikam Maulana

: Alvin Arifin

: 978-602-53090-7-6

: STIEBA Madura Press

: 2019

: Dianda Creative, Yogyakarta

: Rp 50.000 (Tokopedia), Rp.50.000 (Bukalapak)

: Nasional

$: 15,5 \times 23 \mathrm{~cm}$ 


\title{
C. RESENSI BUKU DAN PUISI
}

Berikut adalah potongan puisi berjudul pandai, yakni:

\author{
Aku pandai dalam segala hal \\ Semua orang membutuhkanku \\ Mereka membawaku kemanapun mereka pergi \\ Karenaku segalanya menjadi mudah \\ Apakah aku?
}

Puisi berjudul pandai ini ditulis oleh Agung Purnomo bersama Nur Asitah, yang lahir dan besar di kota Sidoarjo.

Penulis Agung Purnomo selain menulis puisi bertajuk pandai (Purnomo \& Asitah, 2019c), juga menulis syair berjudul sebagai berikut: sepekan awal tanpamu (Purnomo \& Asitah, 2019d), dua kaki (Purnomo, 2018b), tangisnya (Purnomo \& Asitah, 2019e), kita (Purnomo \& Rosyidah, 2019), rindu di ubun-ubun (Purnomo, 2019c), \#CH1 (Purnomo, 2018a), cantik (Purnomo \& Asitah, 2019b), berpulang (Purnomo, 2019a), bapak Samsuri (Purnomo \& Asitah, 2019a), menyala (Purnomo, 2019b), dan dua kaki (Purnomo, 2018b).

Puisi bertajuk pandai termasuk jenis puisi genre riddle yang diterbitkan pada tahun 2019. Puisi riddle adalah puisi teka-teki untuk menstimulan nalar pembaca/ Puisi pandai ini memaparkan tentang barang 
yang dianggap pandai dan pembaca diajak untuk menebaknya. Puisi ketika dibaca cukup ringan dan enak untuk dibaca. Puisi ini, tampaknya, lebih tepat dan bermanfaat bagi para penggemar tebak-tebakan.

Buku antologi puisi berjudul Tolesan Aditi ini terdiri atas beberapa karya puisi dari beberapa penulis. Buku antologi puisi ini membebaskan penulis untuk berkarya tanpa tema tertentu. Cover buku dilaminasi dove sehingga tidak mengkilap ketika dilihat dan di foto. Beberapa masukan untuk perbaikan kualitas buku adalah memberikan riddle yang lebih sulit dan menantang.

\section{KESIMPULAN}

Puisi berjudul pandai di dalam buku antologi puisi bertajuk Tolesan Aditi sangat berguna, khususnya bagi penggemar tebak-tebakan yang menebak suatu benda yang dianggap pintar. Puisi ketika dibaca cukup ringan dan enak untuk dibaca. Jadi, upaya Agung Purnomo patut diberi apresiasi dan direkomendasikan tentunya. 


\section{REFERENCES}

Purnomo, A. (2018a). \#CH1. In Kidung Nawala (Jilid 1). Sidoarjo: UNUSIDA Press.

Purnomo, A. (2018b). Dua Kaki. In Kidung Nawala (Jilid 2). Sidoarjo: UNUSIDA Press.

Purnomo, A. (2019a). Berpulang. In Syair Nimala.

Sumenep: STIEBA Madura Press.

Purnomo, A. (2019b). Menyala. In Tenta Kimaya.

Sumenep: STIEBA Madura Press.

Purnomo, A. (2019c). Rindu di Ubun-Ubun. In

Rassana Jlantir. Sumenep: STIEBA Madura

Press.

Purnomo, A., \& Asitah, N. (2019a). Bapak Samsuri.

In Dhalubang Marta. Sumenep: STIEBA

Madura Press.

Purnomo, A., \& Asitah, N. (2019b). Cantik. In

Lembhar Jiwana. Sumenep: STIEBA Madura

Press.

Purnomo, A., \& Asitah, N. (2019c). Pandai. In

Tolesan Aditi. Sumenep: STIEBA Madura Press.

Purnomo, A., \& Asitah, N. (2019d). Sepekan Awal

Tanpamu. In Arebhan Helai. Sumenep: STIEBA

Madura Press.

Purnomo, A., \& Asitah, N. (2019e). Tangisnya. In

Bhumi Bawera. Sumenep: STIEBA Madura

Press.

Purnomo, A., \& Rosyidah, E. (2019). Kita. In Suweda Ate. Sumenep: STIEBA Madura Press. 